\title{
Abordagem geográfica do Polo Costa das Dunas/RN
}

\section{A geographical approach of the Polo Costa das Dunas/RN}

\author{
Enfoque geográfico del Polo Costa das Dunas / RN
}

José Alexandre Berto de Almada ${ }^{1}$ http://orcid.org/0000-0002-7907-2204

\footnotetext{
${ }^{1}$ Doutorando em Geografia pela Universidade Federal de Pernambuco. Professor Assistente do Departamento de Geografia da Universidade do Estado do Rio Grande do Norte, Campus Mossoró. E-mail: josealmada@uern.br.
}

\section{Resumo}

O presente artigo traz uma abordagem geográfica do Polo Costa das Dunas (PCD), Rio Grande do Norte, levando em consideração os fundamentos teóricos para a sua criação; dados estatísticos oficiais do IBGE, Ministério do Turismo e Ministério do Trabalho, no qual propõem uma regionalização interna com base nos indicadores econômicos, sociais e turísticos e a relação entre produto turístico e oferta turístico com espaço geográfico e território usado, destacando o papel do turismo para o desenvolvimento para as regiões internas do polo. O turismo no momento está sendo insuficiente para o desenvolvimento econômico para todo o PCD, pois concentra-se em Natal e Tibau do Sul, sendo uma atividade de pouca expressividade nos demais municípios do polo.

Palavras-chave: Rio Grande do Norte. Polo Costa das Dunas. Turismo.

\begin{abstract}
This article presents a geographical approach of the Polo Costa das Dunas (PCD), Rio Grande do Norte, taking into account the theoretical foundations for its creation; official statistical data from IBGE, Ministério do Turismo and Ministério do Trabalho, in which they propose an internal regionalization based on economic, social and tourist indicators and the relationship between tourism product and tourism offer with geographical space and used territory, highlighting the role of tourism for development for the pole's internal regions. Tourism now is being insufficient for economic development for the entire PCD, as it is concentrated in Natal and Tibau do Sul, being an activity of little expression in the other municipalities of the pole.
\end{abstract}

Keywords: Rio Grande do Norte. Polo Costa das Dunas. Tourism.

\section{Resumen}

Este artículo presenta un enfoque geográfico de lo Polo Costa das Dunas (PCD), Rio Grande do Norte, teniendo en cuenta los fundamentos teóricos para su creación; Datos estadísticos oficiales del IBGE, el Ministério do Turismo y el Ministério do Trabalho, en los que proponen una regionalización interna basada en indicadores económicos, sociales y turísticos y la relación entre el producto turístico y la oferta turística con el espacio geográfico y el territorio utilizado, destacando el papel del turismo. para el desarrollo de las regiones internas del polo. El turismo en este momento es insuficiente para el desarrollo económico de toda 
la PCD, ya que se concentra en Natal y Tibau do Sul, siendo una actividad de poca expresión en los otros municipios del polo.

Palabras clave: Rio Grande do Norte. Polo Costa das Dunas. Turismo.

Recebido em: 09/02/2019

Aceito para publicação em: 20/04/2020

\section{Introdução}

Os primeiros anos da década de 1990 o litoral do Nordeste brasileiro foi contemplado pelo Programa de Desenvolvimento do Turismo no Nordeste (PRODETUR/NE), no qual teve duas fases entre os anos de 1994 e 2012, investindo, em parceria entre o Banco do Nordeste (BNB) e o Banco Interamericano de Desenvolvimento (BID) no total de US\$ 1,025 bilhão, desse valor, US\$ 75,74 milhões foram aplicados no Rio Grande do Norte (TRIBUNAL DE CONTAS DA UNIÃO, 2004; EQUIPE PCR, 2012).

Além de fomentar o desenvolvimento econômico pelo turismo, o BNB iniciou o processo de agrupamento dos municípios que foram contemplados pelas ações do PRODETUR/NE em polos de desenvolvimento turístico, No total dez polos, distribuídos na região Nordeste e no Norte de Minas Gerais ${ }^{2}$. No Rio Grande do Norte é criado o Polo Costa das Dunas (PCD).

Neste contexto, o presente artigo tem como objetivo analisar o objeto PCD, levando em consideração os fundamentos teóricos para a sua criação, a partir de uma abordagem geográfica, destacando a composição regional deste polo, amparada em dados estatísticos oficiais, colhidos juntos ao IBGE, no qual foi consultado o PIB para o ano de 2016, IDHM, população, densidade demográfica e população ocupada, junto ao banco de dados do RAIS, do Ministério do Trabalho, e também, com o Ministério do Turismo, onde foram extraídos os dados do Mapa do Turismo, buscando compreender o espaço geográfico e o território usado pelo turismo nesta porção do litoral do Rio Grande do Norte.

O trabalho está dividido em três partes. A primeira discute o conceito de polo de crescimento econômico e sua aplicação ao turismo, sobretudo na composição do PCD. A

\footnotetext{
2 São os polos: do Descobrimento, que engloba a Costa do Descobrimento e a Costa das Baleias, Polo Litoral Sul, Polo Salvador e Entorno e o Polo da Chapada Diamantina, no estado da Bahia; do Vale do Jequitinhonha, em Minas Gerais; Polo Costa das Dunas, no Rio Grande do Norte; Polo Costa dos Arrecifes, em Pernambuco; Polo Costa do Sol, no Ceará; e Polo Costa do Delta, no Piauí.
} 
segunda parte propõe uma regionalização interna com base nos indicadores econômicos, sociais e turísticos dos municípios que compõem este polo. A última parte aborda a relação entre produto turístico e oferta turística com espaço geográfico e território usado, destacando o papel do turismo para o desenvolvimento para as regiões internas do PCD.

\section{Os Polos de Crescimento Econômico e o Turismo}

Com o início segunda fase da política pública PRODETUR/NE, em 2002, os municípios que foram beneficiados passaram a ser regionalizados em polos turísticos, sendo essa uma condicionante para acesso ao financiamento público junto ao Banco Interamericano de Desenvolvimento (BID). Essa regionalização é uma iniciativa do Banco do Nordeste, ainda na primeira fase do PRODETUR/NE, quando em 1998 inicia.

o processo de estruturação dos Pólos de Desenvolvimento Integrado de Turismo do Nordeste (Pólos de Turismo). O programa teve por objetivo impulsionar o aproveitamento sustentável da atividade turística através da incorporação de paradigmas empresariais para o fortalecimento dos elos da Cadeia Produtiva do Turismo e assegurar a conseqüência, convergência e continuidade de ações e projetos, a partir da integração de todos os esforços despendidos pelos órgãos públicos e privados, envolvidos com o setor. (BANCO DO NORDESTE DO BRASIL S.A, 2002, p.40).

O litoral leste do Rio Grande do Norte foi uma das áreas beneficiadas pelo PRODETUR/NE, nesta porção do estado é criado o Polo Costa das Dunas (PCD), composto inicialmente pelos municípios que foram beneficiados pelo financiamento da primeira fase do programa, excetuando o município de Goianinha que mesmo tendo recebido US\$ 189,9 mil, corresponde a $1 \%$ dos investimentos (BANCO DO NORDESTE DO BRASIL S.A, 2005) não fez parte do polo.

O Banco do Nordeste (2002, p. 40) destaca que "a materialização dos Polos de Turismo passa a acontecer a partir da instalação dos Conselhos de Turismo", para o PCD este momento é o dia 28 de maio de 1999, justamente a data da criação do Conselho de Turismo do Polo Costa das Dunas, que teve a sua primeira reunião realizada em 08 de junho de 1999.

O Conselho de Turismo do PCD é composto no momento de sua criação por 26 membros: 8 do poder público federal; 7 do poder público estadual; 2 do poder público municipal; 6 do setor privado e 3 do terceiro setor (ALVES, 2009).

$\mathrm{Na}$ lógica organizacional que envolve o PRODETUR/NE, os conselhos de turismo 
[...] são espaços integrados, sistematizados e direcionados, com o objetivo de promover iniciativas que concorram para o desenvolvimento sustentável do Setor, com destaque na identificação de obstáculos existentes na mesorregião, visando a implementação de ações antecedentes e subsequentes à colocação do crédito. (BANCO DO NORDESTE, 2002, p.40).

Além de fomentar o desenvolvimento econômico pelo turismo, a criação dos polos de desenvolvimento pelo Banco do Nordeste teve como base, segundo Alves (2009), a teoria dos polos de crescimento, com destaque para François Perroux e Jacques Boudeville, os principais autores dessa corrente do pensamento construída entre as décadas de 1950 e 1960.

A adoção da teoria dos polos de crescimento não foi aplicada somente para regionalizar os municípios turísticos da região Nordeste, de acordo com Pedroza (2017, p.1)

é amplamente conhecido o fato de que, dentro do planejamento brasileiro, a teoria dos polos de crescimento teve uma grande influência e foi responsável por muitos planos territoriais que moldaram o território, buscando dirimir as desigualdades regionais e integrar os espaços nacionais.

Destarte, a intenção do Banco do Nordeste em pareceria com o BID e os estados nordestinos é desenvolver economicamente os seus territórios litorâneos, dotando-os de materialidades necessárias para atrair investimentos, sobretudo do capital externo, para desenvolver um turismo de massa pautado no modelo de sol e praia, partindo do princípio de que "o polo de desenvolvimento é uma unidade econômica motriz ou um conjunto formado por várias dessas unidades que exercem efeitos de expansão, para cima e para baixo, sobre outras unidades que com ela estão em relação" (LIMA; SIMÕES, 2009, p.8), ou seja, o objetivo era que ao privilegiar uma área central para os investimentos, no qual o desenvolvimento econômico expandiria para as áreas contíguas ao ponto central.

O processo de expansão econômica prevista para os polos a partir de uma área central para áreas periféricas, na escala destacada por Santos (2012) como horizontalidades, segundo Carvalho (1991) denominada de "efeitos de arrasto", no qual "[...] são gerados por indústrias motrizes dinâmicas que não estão presentes em outras aglomerações geográficas" (CARVALHO, 1991, p.8), partindo do princípio de que ao concentrar investimentos de um dado setor econômico para atrair um tipo específico de indústria para um determinado ponto do espaço geográfico irá despertar o interesse de outras indústrias desse setor para se instalar nos arredores dessa área central, passando a ocupar gradativamente os pontos periféricos do polo. 
Segundo Couzon (2003), a noção de indústrias motrizes dinâmicas aparece no trabalho François Perroux com o conceito de empresa, "[...] uma unidade de produção entendida, de acordo com sua definição usual, como um conjunto de meios materiais e pessoais sujeitos a um mesmo poder de disposição econômica" (COUZON, 2003, p. 90). Para apreender os polos de crescimento, Perroux estabelece uma distinção entre o espaço banal, concreto, e o espaço econômico, abstrato, das empresas, o primeiro, corresponde "ao espaço em que estão localizados os meios materiais e humanos em que as empresas estão localizadas: os edifícios, as máquinas, as matérias primas, os salários" (COUZON, 2003, p.90).

O espaço econômico, conforme comentado por Couzon (2003), é um espaço planificado composto por três espaços, o primeiro, diz respeito ao conjunto de relações que a empresa estabelece entre os seus fornecedores e compradores; o segundo, definido como um campo de forças, constituídos por centros produtores e receptores de forças; e, o terceiro espaço econômico é composto pelas relações que a estrutura da empresa estabelece com outras estruturas. Desta forma, quanto mais complexa e maior for a importância de uma determinada empresa em seu espaço econômico, maior deverá ser o seu efeito de arrasto e capacidade de atrair outras empresas para o polo econômico.

Ao analisar criticamente a aplicação da teoria dos polos de crescimento econômico para os países subdesenvolvidos, Santos (1974) destacou que a estrutura do espaço não é composta apenas pela localização das empresas, ao realizar a análise é preciso considerar a estrutura do Estado, da produção e como a disponibilidade dos recursos são atribuídos às diferenças classes sociais, uma vez que ao mesmo tempo que se moderniza uma determinada área em função da polarização de um empresa dinâmica, arrasta-se consigo, de modo desigual e combinado, atividades do circuito inferior da economia, que mais do um obstáculo para o crescimento econômico, fazem parte da estrutura urbana das cidades, e "é por isso que se pode dizer que o crescimento e o circuito inferior ocorrem paralelamente. $\mathrm{O}$ crescimento, em todo caso, tal como ele é comumente definido, não aparece como um processo capaz de eliminar a pobreza (SANTOS, 1974, p.278-279).

A lógica de desenvolvimento pela atividade turística pensada no PRODETUR/NE dá continuidade ao processo de urbanização dual destacada por Santos (2008), no qual para o PCD assume a forma espacial de uma rede de lugares turísticos, com uma concentração das atividades em Natal, sobretudo entre a Via Costeira e praia de Ponta Negra, na zona da sul da capital, marcada pela presença dos empreendimentos do circuito superior do turismo.

A teoria dos polos de crescimento econômico aplicada ao turismo diverge entre a sua proposição e aplicação, pois, a concentração da atividade turística na capital deveria promover 
um enfeito de arrasto, em função dos empreendimentos do circuito superior ligados ao modelo de turismo de sol , passando a atrair investimentos para os demais áreas litorâneas dos municípios que compõem o polo. Entretanto, concomitante as atividades do grande capital também houve a presença do circuito inferior tanto na praia de Ponta Negra (MEDEIROS, 2014) como em outros lugares turísticos do PCD como as praias as praias de Redinha Nova e Jenipabu, em Extremoz (ALMADA, 2016).

De certo modo o efeito arrasto conseguiu expandir atividade turística para praticamente todo o litoral do PCD, porém, essa expansão ocorreu com uma presença massiva dos pequenos empreendimentos e trabalhadores ambulantes que compõem a massa do circuito inferior do turismo, pois, conforme destaca Santos $(1974$, p.272), “[...] a teoria dos polos de crescimento na maioria de suas formulações tradicionais ou recentes se interessa pelo espaço de alguns e não com os espaços de todos" desta forma, "a teoria dos polos de crescimento, como todas as outras teorias espaciais, diz respeito apenas ao circuito superior" (SANTOS, 1974, p. 278), não levando em consideração o papel do circuito inferior no processo de urbanização, desta forma, o turismo, enquanto atividade econômica, em muitas das praias do PCD contribui mais para a subsistência das pessoas que estão envolvidas com esta atividade do que para o desenvolvimento econômico do lugar.

\section{Regionalização do Polo Costa das Dunas}

O Polo Costa das Dunas, localizado no litoral leste do Rio Grande do Norte, com uma área de 4.826,507 km² e com uma estimativa de 1.626 .982 habitantes para o ano de 2017 (IBGE, 2019b) abrangendo atualmente 17 municípios: Pedra Grande; São Miguel do Gostoso; Touros; Rio do Fogo; Maxaranguape; Ceará-Mirim; Extremoz; São Gonçalo do Amarante; Natal; Macaíba; Parnamirim; São José do Mipibu; Nísia Floresta; Sen. Georgino Avelino; Tibau do Sul; Canguaretema e Baía Formosa.

O Decreto estadual 18.186/2005, definia em seu Art. $1^{\circ}$ que este polo é um "espaço sócio econômico homogêneo com vantagens competitivas e vocacionais, com o objetivo de integrar a cadeia produtiva do turismo" (RIO GRANDE DO NORTE, 2005, p.1), porém, além de não ser esse espaço homogêneo, ao levar em consideração os aspectos sociais e econômicos de cada município, o PCD também não é um espaço competitivo, uma vez que Natal concentrou 76,3\% da receita turística do estado em 2012 (SETUR,2013) e 54\% da média dos indicadores relacionados a meio de hospedagem em 2009 (BRASIL, 2011), ou seja, o turismo enquanto atividade econômica se especializou e se especializou. 
A composição do PCD enquanto região é resultado da aplicação da teoria do polo de crescimento econômico, porém, sua no contexto no litoral potiguar, pelo PRODETUR/NE, polarizou em Natal o centro dessa rede urbana, gerando disparidades internas, principalmente a nível de desenvolvimento, não conseguindo promover uma região homogênea, conforme pretendia o decreto de criação deste polo.

Por meio dos os aspectos empíricos, o que está posto no espaço geográfico, e a perspectiva teórica, o conjunto de ideias sistematizadas para regionalizar as porções do espaço, Haebaesrt (2014, p.109, grifos do autor) apresenta o conceito de região como artefato, isto é, compreender a região "[...] não simplesmente como um 'fato'(concreto), um 'artifício' (teórico) ou um instrumento de ação, mas da região como um 'artefato', tomada na imbricação entre fato e artifício e, de certo modo, também, enquanto ferramenta política".

A proposta de análise regional de Haesbaert (2014) compreende a região artefato como produto-produtora dos processos de diferenciação espacial; como produto-produtora das dinâmicas concomitantes de globalização e fragmentação, em suas distintas combinações e intensidades e construída através da atuação de diferentes sujeitos sociais.

Sobre o fato, isto é, a realidade empírica, temos que há uma divisão da costa leste do estado, a qual se localiza o polo Costa das Dunas, entre um litoral sul e um litoral norte, tendo como ponto de referência a cidade Natal. A partir deste referencial locacional, as agências de viagens oferecem pacotes de passeios para o litoral norte e ao litoral sul, a exemplo, a o site Natal Online (NATAL ONLINE, 2019) que classifica o litoral norte a partir da praia de Jenipabu, município de Extremoz, até São Miguel do Gostoso, dentro do polo Costa das Dunas, e também os municípios de Galinhos, Macau e a praia de Ponta do Mel, em Areia Branca, na costa norte do estado e pertencem ao polo Costa Branca. Para o litoral sul, a lista de destinos inicia na praia de Cotovelo, Parnamirim, até o município de Baía Formosa, ambos no PCD.

A divisão entre litoral norte e litoral sul já está posta na prática turística, tendo como referencial natural o Rio Potengi, que cinde Natal em margem sul, onde estão presentes as Zonas Leste, Oeste e Sul, e a margem norte que compreende toda a Zona Norte, essa última segundo Bezerra e Araújo (2007) também é conhecida como o outro lado do rio, para além de sua localização, a característica principal desta porção da capital é a sua relativa condição de inferioridade, no quesito de acessibilidade, de infraestrutura, de serviços urbanos e de renda (BESERRA; ARAÚJO, 2007).

Na perspectiva da análise regional proposta por Haesbaert, em que a composição de uma região é resultado de uma amálgama entre o fato e o artifício, isto é 
[...] uma região como arte-fato (com hífen), no meio de um continuum que se estende desde o recorte analítico, instrumento metodológico proposto pelo investigador para efeito de sua pesquisa, até o espaço de concretas de sujeitos sociais que efetivamente constroem articulações regionais, sejam eles hegemônicos (como as empresas e o Estado), sejam subalternos (como os povos tradicionais). (HAESBART, 2019, p.119-120).

Destarte, a regionalização do Polo Costa Dunas parte do fato empírico da prática turística que cinde o litoral deste polo. Tendo como referência a sua composição municipal atual outorgada pelo Decreto $\mathrm{N}^{\mathrm{0}} 26.661 / 17$, a região do Litoral Norte é composta pelos municípios litorâneos imediatamente ao norte de Natal, Extremoz, Ceará-Mirim, Maxaranguape, Rio do Fogo, Touros, São Miguel do Gostoso e Pedra, em respectiva ordem decrescente em sentido latitudinal sul. A região do Litoral Sul, pelos municípios ao sul da capital, Parnamirim, São José do Mipibu ${ }^{3}$, Nísia Floresta, Senador Georgino Avelino, Tibau do Sul, Canguaretama e Baía Formosa, em respectiva ordem crescente em sentido latitudinal sul.

Entre o Litoral Norte e o Litoral Sul estão os municípios de São Gonçalo do Amarante, Macaíba e Natal, esta última, capital do estado, que se localiza a área central de toda atividade turística do Rio Grande do Norte, justamente os equipamentos turísticos, como grandes cadeias hoteleiras e serviços especializados na recreação turística, localizadas nas praias da Via Costeira de Ponta Negra, na Zona Sul da cidade, compondo desta forma, a região do Litoral Central do Polo Costa das Dunas.

O município de São Gonçalo do Amarante, embora esteja em uma área de conurbação urbana direta com a Zona Norte de Natal, nesta proposição de regionalização para PCD ele integra o Litoral Central e não do Litoral Norte, pois, primeiramente não é um município litorâneo, logo não possui a mesma formação socioespacial dos demais municípios do Litoral Norte e, também, por sua dinâmica urbana associada está associada diretamente com a cidade de Natal, em função do aeroporto internacional Aluísio Alves, em funcionamento desde 2014, em seu território. Em função deste motivo que o município de Macaíba, que também não é litorâneo, também faz parte do Litoral Central e não do Litoral Sul, pois constitui uma opção de acesso entre o aeroporto internacional e a Zona Sul via BR-304, sem passar pela Zona Norte da cidade.

Na regionalização proposta para o Polo Costa das Dunas, o Litoral Norte é composto por sete municípios, o Litoral Central por três municípios e o Litoral Sul por sete municípios (mapa 1).

\footnotetext{
${ }^{3}$ Esse município embora não seja litorâneo, foi adicionado ao Polo Costa das Dunas pelo Decreto No 26.661/17, e por esse motivo está sendo considerado como parte do litoral sul. 
Mapa 1 - Regionalização do Polo Costa das Dunas - 2020

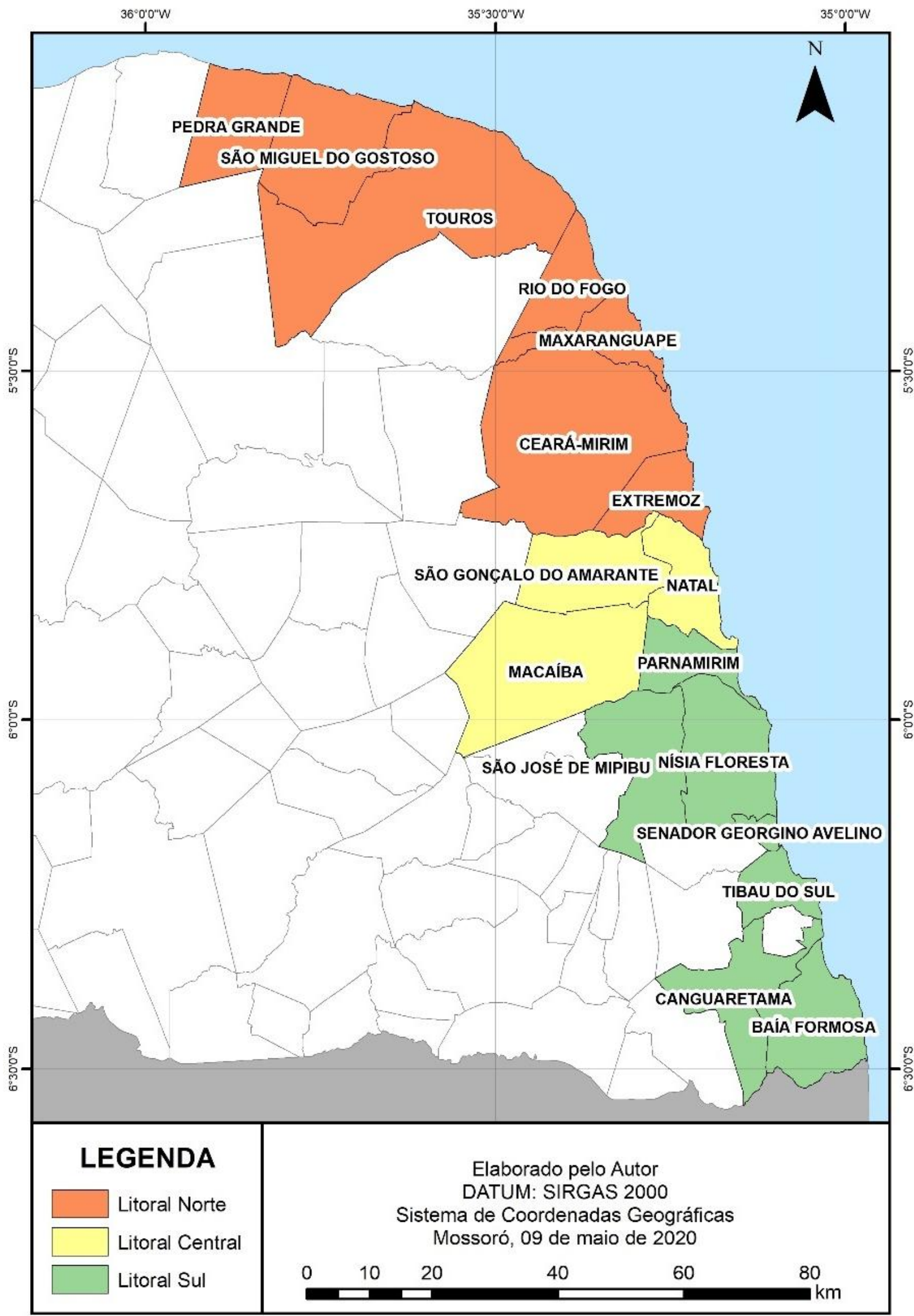

Fonte: Almada (2020). 
A região também é um construto fruto de um artifício, a partir de variáveis específicas do ponto de vista teórico, desta forma, elencou-se os seguintes indicadores para destacar as contradições internas dentro do PDC os seguintes indicadores: econômicos: valor adicionado bruto dos Serviços, a preços correntes - exclusive Administração, defesa, educação e saúde públicas e seguridade social; Produto Interno Bruto, a preços correntes e Produto Interno Bruto per capita para o ano de 2016.

Os indicadores Sociais tais como: Índice de Desenvolvimento Humano Municipal para o ano de 2010; pessoal ocupado; população e densidade demográfica para ano de 2017 e indicadores turísticos: quantidade de empregos em hospedagem; quantidade de estabelecimentos de hospedagem; demanda turística internacional; demanda turística doméstica e demanda turística por habitante ano para o ano de 2017, financiamento público para o turismo, número de empresas de turismo, e o número de seus empregados, com bases dos dados do IBGE, Ministério do Turismo e Ministério do Trabalho.Ao agrupar os dados econômicos dos municípios do PCD de acordo as regiões propostas, o Litoral Norte aparece com os menores indicadores, com 7,2\% do PIB e 3,9\% do PIB em, seguido pelo Litoral Sul, com 20,5\% do PIB e 17,8\% do PIB em serviços e o Litoral Central, com 72,3\% do PIB e 78,3\% do PIB em serviços do polo, conforme destaca a tabela 1.

Tabela 1 - Indicadores econômicos do Polo Costa das Dunas - 2016.

\begin{tabular}{|c|c|c|c|}
\hline Região & $\begin{array}{c}\text { PIB em serviços* - }(\mathbf{R} \$ \\
1.000)\end{array}$ & $\begin{array}{c}\text { PIB } \\
(\mathbf{R} \$ 1.000)\end{array}$ & PIB per capita $(\mathrm{R} \$ 1,00)$ \\
\hline $\begin{array}{l}\text { Litoral } \\
\text { Norte }\end{array}$ & $661.503,89$ & $2.449 .256,78$ & $14.012,72$ \\
\hline $\begin{array}{l}\text { Litoral } \\
\text { Central }\end{array}$ & $13.223 .499,02$ & $24.526 .257,95$ & $23.212,50$ \\
\hline $\begin{array}{c}\text { Litoral } \\
\text { Sul }\end{array}$ & $3.002 .546,16$ & $6.955 .859,57$ & $18.285,98$ \\
\hline
\end{tabular}

Além do PIB e do valor adicionado dos serviços ao PIB, o Litoral Norte também apresenta o PIB per capita mais baixo do polo, com valor de $\mathrm{R} \$ 14,012,72$, menos da metade da média nacional para o ano de 2016, que foi de R $\$ 30.407,00$ (IBGE, 2020), consolidando-se desta forma como a região com menor destaque econômico.

Os indicadores sociais (tabela 2) seguem a mesma tendência dos indicadores econômicos, com Litoral Norte na última posição, seguido pelo Litoral Sul e Litoral Central, 
em todos os quatro indicadores destacados, ou seja, entre as três regiões do PCD, o Litoral Norte é a que apresenta o menor desenvolvimento social e econômico.

Tabela 2 - Indicadores sociais do Polo Costa das Dunas.

\begin{tabular}{|c|c|c|c|c|c|}
\hline \multirow[t]{2}{*}{ Região } & \multirow{2}{*}{$\begin{array}{c}\mathbf{2 0 1 0} \\
\text { IDHM - } \\
\text { Médio }\end{array}$} & \multicolumn{4}{|c|}{2017} \\
\hline & & $\begin{array}{l}\text { Pessoal } \\
\text { Ocupado }\end{array}$ & $\begin{array}{c}\text { População } \\
\text { Ocupada }(\%)\end{array}$ & População & $\begin{array}{l}\text { Densidade Demográfica } \\
\left(\mathrm{hab} / \mathrm{km}^{2}\right)\end{array}$ \\
\hline $\begin{array}{l}\text { Litoral } \\
\text { Norte }\end{array}$ & 0,596 & 16.369 & 9,5 & 172.309 & 67,43 \\
\hline $\begin{array}{l}\text { Litoral } \\
\text { Central }\end{array}$ & 0,688 & 348.750 & 32,7 & 1.066 .703 & 1150,34 \\
\hline $\begin{array}{c}\text { Litoral } \\
\text { Sul }\end{array}$ & 0,629 & 66.749 & 17,2 & 387.970 & 288,68 \\
\hline
\end{tabular}

Apesar do Litoral Norte ter a menor população, levando em consideração a projeção para o ano de 2017, é a região que possuí a maior área dentro do polo, impactando diretamente sua densidade demográfica, que é quatro vezes menor que a do Litoral Sul e dezessete vezes menor que a do Litoral Central, desta forma, apresenta-se como a região menos populosa e povoada.

Os baixos indicadores econômicos e sociais contextualizam o Litoral Norte no cenário turístico como a região com a menor infraestrutura para receber essa atividade. Com os destaques dos indicadores turísticos, (tabela 3), novamente essa região encontra-se os piores números, com uma atividade turística que ainda não está consolidada e não consegue ser um motor para o desenvolvimento local.

Tabela 3 - Indicadores turísticos do Polo Costa das Dunas - 2017.

\begin{tabular}{ccccccc}
\hline $\begin{array}{c}\text { Fonte: } \\
\text { Região }\end{array}$ & $\begin{array}{c}\text { ÁREA } \\
\left(\mathbf{k m}^{2}\right)\end{array}$ & $\begin{array}{c}\mathbf{N}^{\mathbf{0}} \text { Empregos } \\
\text { Hospedagem }\end{array}$ & $\begin{array}{c}\mathbf{N}^{\mathbf{2}} \\
\text { Estabelecimentos } \\
\text { Hospedagem }\end{array}$ & $\begin{array}{c}\text { Demanda } \\
\text { Internacional }\end{array}$ & $\begin{array}{c}\text { Demanda } \\
\text { Doméstica }\end{array}$ & $\begin{array}{c}\text { Demanda } \\
\text { turística } \\
\text { por hab. } \\
\text { Ano }\end{array}$ \\
\hline $\begin{array}{c}\text { Litoral } \\
\text { Norte }\end{array}$ & $2.555,27$ & 253 & 58 & 4.114 & 112.385 & 0,68 \\
\hline $\begin{array}{c}\text { Litoral } \\
\text { Central }\end{array}$ & 927,29 & 4.446 & 162 & 114.192 & 3.201 .131 & 3,11 \\
\hline $\begin{array}{c}\text { Litoral } \\
\text { Sul }\end{array}$ & $1.343,94$ & 1.117 & 131 & 54.788 & 243.475 & 0,77 \\
\hline
\end{tabular}

Fonte: Brasil (2018).

A partir da demanda turística por habitante no ano, obtida pela resultado da soma da demanda internacional e da demanda nacional de turistas pelo número de habitantes de cada região do polo, o Litoral Norte e o Litoral Sul aproximam-se, com 0,68 e 0,77 respectivamente, entretanto, o Litoral Sul é 2,2 vezes mais populoso que e o Litoral Norte, ou 
seja, mesmo com índices próximos, ao considerar o número efetivo da soma da demanda internacional e nacional o Litoral Sul é mais procurado.

Outrossim, dentro polo, o Litoral Sul possuí quatro dos cincos munícipios, em que Natal, no Litoral Central, está no topo da lista, com maior demanda turística, em ordem decrescente, Tibau do Sul, Parnamirim, Baía Formosa e Canguaretama. É também no Litoral Sul que possuí os melhores índices de demanda turística por habitante no ano, justamente Baía Formosa com 8,0 e Tibau do Sul, com 7,1, este último com destaque para o turismo internacional, sendo o único dos municípios do PCD em que a demanda internacional é maior que a nacional.

O potencial de atratividade turística de cada região do polo, também, pode ser entendida a partir do conceito de oferta turística apresentado por Beni (2001), combinado por duas grandes categorias, a primeira, também chamada de oferta turística original, é composta pelos “[...] elementos turísticos primários de um país, que constituem sua oferta original, são 'bens livres' e, mais particularmente, no que concerne ao patrimônio turístico, são atrativos que provêm quer da natureza quer dos legados histórico-culturais” (BENO, 2001, p. 163).

A oferta original no PCD é composta, principalmente, pelos elementos naturais que compõem a paisagem, uma vez que o seu modelo de desenvolvimento pelo turismo é o de sol e praia, no qual suas as praias e lagoas metamorfoseiam-se em atrativos turísticos em potencial, justificando junto as instituições de fomento o agrupamento desses municípios litorâneos em um polo de crescimento econômico, visando utilizar esses atributos naturais na composição de um produto turístico.

Se apenas a oferta original fosse necessária para garantir a presença de turistas o Polo Costa de Dunas de fato já seria um polo de crescimento econômico consolidado, uma vez que todo o seu litoral dispõem da mesma morfologia costeira, com a presença de praias, dunas e lagoas interdunares (NUNES, 2006), porém, o segundo elemento que compõe a oferta turística, conforme destacado por Beni (2001), corrobora no entendimento do que ainda falta para o Litoral Sul e, principalmente, o Litoral Norte para encontrar no turismo a fonte para desenvolvimento, justamente a oferta turística derivada, que

é composta pelos transportes, pelas diversas formas de alojamento, lazer e recreação, pelos organizadores de viagens, e pelas agências de viagem. Ela não pode satisfazer a demanda a não ser que haja uma combinação entre os diversos fatores da oferta derivada e da oferta original. (BENI, 2001, p. 163).

A oferta turística derivada, na qual fazem parte os diversos tipos de empresas de turismo, constitui a principal variável na diferenciação regional, ao levar em consideração o critério de desenvolvimento econômico pelo turismo, no Polo Costa das Dunas. Em 
perspectiva lógica, quanto melhor estruturada a disposição da oferta turística derivada, a partir da distribuição das mais diversas empresas de turismo no lugar, maior é participação do turismo na dinâmica econômica.

Para identificar a oferta turística derivada nas regiões e PCD e ajudar a construir o entendimento do desenvolvimento, ou não, pelo turismo recorreu-se a base nos dados da Relação Anual de Informações Sociais (RAIS), instituída pelo Decreto N76.900/1975, na qual é possível identificar o número de estabelecimentos, e seus vínculos empregatícios, das empresas que constituem este tipo de oferta turística de cada um dos municípios as regiões do polo em análise, desta forma, selecionou-se neste banco de dados, para o período de 2018, as variáveis: Transportes, terrestre, aquaviário e aéreo; Alojamento; Alimentação; Agências de Viagens, Operadores Turísticos e Serviços de Reservas; Atividades Ligadas ao Patrimônio Cultural e Ambiental e Atividades Esportivas e de Recreação e Lazer, resultando nos seguintes dados, (tabelas 4 e 5).

Tabela 4 - Estabelecimentos turísticos do Polo Costa das Dunas - 2018.

\begin{tabular}{cccc}
\hline ATIVIDADE & LITORAL NORTE & LITORAL CENTRAL & LITORAL SUL \\
\hline Transporte Terrestre & 51 & 498 & 290 \\
\hline Transporte Aquaviário & 13 & 13 & 25 \\
\hline Transporte Aéreo & 0 & 9 & 13 \\
\hline Alojamento & 90 & 329 & 691 \\
\hline Alimentação & 168 & 2.124 & 46 \\
\hline $\begin{array}{c}\text { Agências de Viagens, } \\
\text { Operadores Turísticos e } \\
\text { Serviços de Reservas }\end{array}$ & 20 & 227 & 3 \\
\hline $\begin{array}{c}\text { Atividades Ligadas ao } \\
\text { Patrimônio Cultural e } \\
\text { Ambiental }\end{array}$ & 1 & 5 & 131 \\
\hline $\begin{array}{c}\text { Atividades Esportivas e } \\
\text { de Recreação e Lazer }\end{array}$ & 39 & 434 & 1.441 \\
\hline TOTAL & 382 & 3.639 & \\
\hline
\end{tabular}

Fonte: Ministério do Trabalho (2020).

A oferta turística derivada, com base nos dados das tabelas 5 e 6 , segue a tendência dos outros indicadores, econômicos, sociais e turísticos, com o Litoral Central possuindo a grande maioria dos estabelecimentos e vínculos turísticos do PCD, concentrando $66,6 \%$ e $75,8 \%$ respectivamente. O Litoral Norte também aparece com os piores números, com 7,0\% dos estabelecimentos e 4,5\% dos vínculos e o Litoral Sul na posição intermediária, com $26,4 \%$ e $19,7 \%$ dos estabelecimentos e vínculos turísticos respectivamente. 
Tabela 5 - Vínculos em estabelecimentos turísticos Do Polo Costa das Dunas - 2018.

\begin{tabular}{|c|c|c|c|}
\hline ATIVIDADE & LITORAL NORTE & LITORAL CENTRAL & LITORAL SUL \\
\hline Transporte Terrestre & 86 & 7.339 & 2.446 \\
\hline Transporte Aquaviário & 67 & 242 & 97 \\
\hline Transporte Aéreo & 0 & 350 & 55 \\
\hline Alojamento & 866 & 7.305 & 2.239 \\
\hline Alimentação & 631 & 16.917 & 3.952 \\
\hline $\begin{array}{l}\text { Agências de Viagens, } \\
\text { Operadores Turísticos e } \\
\text { Serviços de Reservas }\end{array}$ & 30 & 916 & 49 \\
\hline $\begin{array}{c}\text { Atividades Ligadas ao } \\
\text { Patrimônio Cultural e } \\
\text { Ambiental }\end{array}$ & 62 & 58 & 7 \\
\hline $\begin{array}{l}\text { Atividades Esportivas e } \\
\text { de Recreação e Lazer }\end{array}$ & 339 & 2.118 & 341 \\
\hline TOTAL & 2.081 & 35.245 & 9.186 \\
\hline
\end{tabular}

Fonte: Ministério do Trabalho (2020).

As três regiões do Polo Costa Dunas configuram-se como espaços com características naturais semelhantes, no que diz respeito a sua composição climática e geomorfológica que compõem o elemento central de sua oferta turística original, porém, ao considerar a combinação desses elementos com a demanda turística derivada, com base nos dados da RAIS, tem-se uma relação de desenvolvimento desigual dentro do polo, pois cada região compete pelo visitação dos mesmos turistas, porém, esses tendem a preferir os lugares turísticos do Litoral Central e Sul, pois nestes se localizam a grande maioria das empresas turísticas e a maior probabilidade de que o turista consiga satisfazer sua necessidade de consumo ao visitar o Rio Grande do Norte do que se fosse visitar o Litoral Norte.

\section{Espaço geográfico e território usado pelo turismo nas regiões do Polo Costa das Dunas}

O geográfico do espaço é composto pelas condições existenciais que preenchem o planeta de formas, funções e estruturas construídas processualmente no decorrer da história pelos humanos para os humanos, desta forma, esse conjunto indissociável entre o sistema de objetos e o sistema de ações apresentado por Santos (2012), isso é o espaço geográfico, como objeto central de estudo da Geografia, enquanto ciência, é muito mais do que a relação do homem, na figura da sociedade, e do meio, substrato material, pois, conforme discutido em Almada (2013) a única forma de existir da humanidade é neste planeta e esse por sua vez só se torna mundo com a humanidade, nesse sentido a humanidade é com o meio, ao mesmo 
tempo, de modo indissociável, ou seja, os objetos, substrato material, e as ações, as funções sociais que animam essas formas, existindo em uma solidariedade obrigatória.

Cada ação humana necessita de uma materialidade obrigatória, deste modo, o Lugar Turístico é forma espacial para existência da atividade turística. A oferta turística original e derivada destaca por Beni (2001), em uma leitura geográfica, pode ser compreendida como a configuração territorial existente para o turismo, e o que o autor identifica como produto turístico pode ser entendido, nesta mesma lógica, como o território usado pelo turismo.

Comentando sobre a natureza diferenciada do produto turístico em relação aos outros bens produzidos, a partir do seu caráter temporal, que obriga este produto ser consumido no momento de sua produção, Beni (2001, p.170) destaca que

o produto turístico tem as seguintes características gerais: está baseado no fator tempo; é irrecuperável se não for usado; não pode ser acumulado; não pode ser transportado nem transferido; sua matéria-prima não se agrupa; é extremamente dinâmico e instável, pelos gostos, preferências, modas; e opcional na escala da necessidades do consumidor, razão por que sua demanda é extremamente elástica.

O produto turístico só existe no momento que o turista está no Lugar Turístico vivenciando a paisagem e consumindo os bens e serviços relacionados a essa atividade econômica, ou seja, o produto turístico é o território usado pelo turismo, resultado da produção do espaço pelo turismo, por meio do Estado e do Mercado, e do seu consumo pelos Turistas.

A presença do Estado na composição do produto turístico encontra-se nas "précondições básicas para investimentos turísticos”, ou seja, a infraestrutura básica, “[...] representadas pelo traçado de estradas, saneamento básico e ambiental, serviços municipais, como energia, água, esgoto e outros, que permitam à empresa de turismo operar com maior eficiência" (BENI, 2001,p.171).

Para o Polo Costa das Dunas essas pré-condições para os investimentos turísticos foram possibilitadas pelos investimentos da primeira e segunda fase do PRODETUR/NE, que investiu US\$75,74 milhões, entre 1994 e 2012 no Rio Grande do Norte para melhorar, ou criar, a infraestrutura básica para o desenvolvimento do turismo enquanto atividade econômica com destaque para a reestruturação produtiva no Rio Grande do Norte, conforme escrutinado no terceiro capítulo.

A partir dessas pré-condições que o produto turístico pode existir, uma vez que o seu processo produtivo 
realiza-se mediante a exploração dos recursos turísticos, ou seja, os atrativos naturais e culturais com que conta um determinado país, combinados com tecnologia, trabalho e capital. As unidades em que se organiza esse processo são as empresas prestadoras de serviços e seu resultado chama-se "produto turístico". (BENI, 2001, p.172).

A produção do espaço pelo turismo ocorre pela ação do Estado ao possibilitar as précondições básicas, isto é a infraestrutura, pela ação do Mercado, as empresas de turismo, ao ressignificar as paisagens para torna-las interessantes a visitação e pela implementação de empresas turísticas, e pelos Turista que consomem o produto turístico, ou seja, um Lugar turístico se concretiza a partir do território usado pelo turismo, figurado pela ação cotidiana do Mercado e Turista na produção e consumo do produto turístico e pelo Estado enquanto planejador e fomentador das políticas públicas.

O território usado pelo turismo acontece a partir do momento em que existe uma oferta derivada, pois, somente com a oferta original o turismo é apenas uma possibilidade, um desejo ou uma aposta para o desenvolvimento econômico pelo turismo, nesse momento o lugar inicia o seu processo de refuncionalização de suas paisagens, ao encontrar na praia, na montanha, no campo, no centro histórico um motivo para ser visitado por viajantes, o lugar metamorfoseia-se em lugar turístico.

Porém, a completude, de espaço geográfico em ação, ou seja, o território usado, só ocorre quando de fato o Mercado também se interessa por essa área ao instalar-se por meio das empresas de turismo, a oferta derivada, momento em que pode ocorrer a relação de produção e consumo do produto turístico a partir da presença de turista, tendo neste momento o território usado pelo turismo, momento em que o processo de transformação de lugar e Lugar Turístico é finalizado.

Se o turismo não consegue ser um agente para o desenvolvimento para todo o Rio Grande do Norte como identificar a participação desta atividade para a economia dos municípios? Como ponto de partida para esta identificação pode se utilizar os dados do PIB disponibilizados pelo IBGE (2019b), no qual destacam quais as atividades com maior valor adicionado ao bruto do ano, para turismo considera-se os municípios que destacam os "demais serviços", isto é, excetuando os serviços ligados a administração, defesa, educação e saúde públicas e seguridade social, pois estes, a atividade turística pode ter uma expressão econômica significativa para o desenvolvimento.

Nos dados do PIB do ano de 2016 (IBGE, 2019b), os municípios integrantes ao Litoral Central têm os "demais serviços, como principal valor adicionado ao bruto". Cinco dos sete municípios do Litoral Norte destacaram a “administração, defesa, educação e saúde públicas e 
seguridade social”, justamente os municípios de Touros; Rio do Fogo; Maxaranguape; CearáMirim e Extremoz, enquanto os municípios de Pedra Grande e São Miguel do Gostoso têm nas atividades de "Eletricidade e gás, água, esgoto, atividades de gestão de resíduos e descontaminação" e "Indústrias de transformação" seus principais valores adicionados ao bruto.

No Litoral Sul, os municípios de Parnamirim e Tibau do Sul têm os "demais serviços" como principal contribuição ao PIB, ressaltando que esse último é o único município fora Natal que recebe a classificação "A" na classificação por cluster proposta pelo Mapa do Turismo. O município Senador Georgino Avelino tem na "Produção florestal, pesca e aquicultura" sua principal atividade econômica, enquanto os demais municípios, São José do Mipibu; Nísia Floresta; Canguaretama e Baía Formosa encontram na "administração, defesa, educação e saúde públicas e seguridade social", como principal fonte de renda.

No cenário dos dezessete municípios que compõem o PCD apenas cinco poderiam encontrar no turismo como a principal atividade para o desenvolvimento econômico, conforme espacializa o mapa 3. A partir desta constatação é possível cruzar esses dados com os dados do RAIS e do IBGE cidade para identificar nesses cinco municípios a proporção do pessoal ocupado em empresas de turismo em relação ao total do pessoal ocupado para o ano de 2017 (tabela 6):

Tabela 6 - pessoal ocupado em empresas de turismo de municípios do Polo Costa das Dunas que destacam os demais serviços como principal atividade econômica - 2017.

\begin{tabular}{ccccc}
\hline Município & Região & $\begin{array}{c}\text { Pessoal ocupado em } \\
\text { empresas de turismo }\end{array}$ & $\begin{array}{c}\text { Pessoal } \\
\text { ocupado }\end{array}$ & $\begin{array}{c}\text { \% pessoal ocupado em } \\
\text { empresas de turismo }\end{array}$ \\
\hline $\begin{array}{c}\text { S. Gonçalo do } \\
\text { Amarante }\end{array}$ & $\begin{array}{c}\text { Litoral } \\
\text { Central }\end{array}$ & 2.641 & 13.130 & 20,1 \\
\hline Natal & $\begin{array}{c}\text { Litoral } \\
\text { Central }\end{array}$ & 32.984 & 324.221 & 10,2 \\
\hline Macaíba & $\begin{array}{c}\text { Litoral } \\
\text { Central }\end{array}$ & 695 & 11.399 & 6,1 \\
\hline Parnamirim & Litoral Sul & 4.495 & 46.678 & 10,6 \\
\hline Tibau do Sul & Litoral Sul & 2.798 & 4.178 & 67,0 \\
\hline
\end{tabular}

Fonte: IBGE (2019a); MINISTÉRIO DO TRABALHO (2020).

Apesar do de São Gonçalo do Amarante não ser um município litorâneo aparece em segundo lugar na proporção de pessoal ocupado em empresas de turismo, com $20,1 \%$ dos vínculos. Neste município os vínculos relacionados a empresas de transporte terrestre contribuem com $62,7 \%$ desse valor, com o total 1.657 vínculos. Esse número pode ser justificado em função de sua área conturbada com Natal, possuindo diversas linhas de ônibus 
intermunicipais e transportes urbanos alternativos que trafegam de segunda a segunda em vários horários ao longo do dia.

São de Gonçalo do Amarante não possui nenhum Lugar Turístico de Sol e Praia, sua função para o polo para o Polo Costa das Dunas é sediar o Aeroporto Internacional Governador Aluísio Alves, inaugurado em 2014 em decorrência da Copa do Mundo realizada no Brasil que teve Natal com uma das cidades sedes, comportando-se como uma via de acesso aérea para o estado, desta forma, apesar de um significativo número de pessoal ocupados em empresas de turismo este não é um município com uma atividade econômica voltada para esse setor.

Dos municípios que destacam os "demais serviços" como principal contribuição ao PIB (tabela 7), apenas Tibau do Sul, onde se localiza a praia de Pipa, um destino turístico consolidado no estado, onde o fluxo turístico internacional é maior que o nacional, contrariando a tendência nacional, cujo turismo volta-se para a demanda doméstica (THÉRY, 2015), o turismo tem uma papel determinante para a economia local, uma vez que m $67 \%$ dos vínculos ocupacionais são em empresas de turismo. Desses, 57,7\% são em empresas de alojamento, uma atividade econômica que existe em função do turismo, que empregou no ano de 20171.118 pessoas.

Considerando o pessoal ocupado em empresas de turismo no cenário regional do PCD, no ponto de vista dos empregos formais, para o polo tem-se que para o ano de $2017,10,5 \%$ do pessoal ocupado no Litoral Norte possuíam vínculo em empresas de turismo; $10,4 \%$ no Litoral Central e 13,5\% no Litoral Sul (tabela 7).

Tabela 7 - Pessoal ocupado em empresas de turismo no Polo Costa Das Dunas - 2017.

\begin{tabular}{cccc}
\hline \multicolumn{3}{c}{$\mathbf{2 0 1 7}$} \\
\hline Região & $\begin{array}{c}\text { Pessoal ocupado em empresas } \\
\text { de turismo }\end{array}$ & $\begin{array}{c}\text { Pessoal } \\
\text { ocupado }\end{array}$ & $\begin{array}{c}\text { \% pessoal ocupado em } \\
\text { empresas de turismo }\end{array}$ \\
\hline $\begin{array}{c}\text { Litoral } \\
\text { Norte }\end{array}$ & 1.725 & 16.369 & 10,5 \\
\hline $\begin{array}{c}\text { Litoral } \\
\text { Central }\end{array}$ & 36.320 & 348.750 & 10,4 \\
\hline $\begin{array}{c}\text { Litoral } \\
\text { Sul }\end{array}$ & 8.988 & 66.749 & 13,5 \\
\hline Fonte: IBGE (2019b); MINISTÉRIO DO TRABALHO $(2020)$. &
\end{tabular}

No cenário regional que se desenha para esse polo de crescimento econômico pelo turismo, esta atividade não consegue se irradiar de forma equitativa, e o Litoral Norte apesar de ter um número proporcional de vínculos empresas de turismo maior que o Litoral Central, o número real, corresponde a apenas 1.725 vínculos, equivalente a $3,7 \%$ do total para a 
região. Se o turismo é o motor para o desenvolvimento econômico para o Rio Grande do Norte para o Polo Costa das Dunas, sobretudo no Litoral Norte, ainda não encontrou o combustível necessário para começar a ignição deste motor.

\section{Considerações finais}

Na perspectiva da teoria dos polos de crescimento, que estruturou a regionalização dos municípios beneficiários da política pública do PRODETUR/NE e no Rio Grande do Norte crio o Polo Costa das Dunas, ao centralizar o financiamento público em Natal, e nos municípios vizinhos, como Parnamirim que recebeu 53\% dos recursos da primeira fase programa para ampliação do aeroporto internacional Augusto Severo (BANCO DO NORDESTE DOBRASIL S.A, 2005), pretendeu-se melhorar o oferta original do produto turístico potiguar, atraindo empresas do circuito superior turismo, para que por meio de uma oferta turística derivada com empresas consolidadas nesse setor econômico o litoral leste do estado viesse a possuir lugares turísticos competitivos no cenário turístico de sol e praia do Nordeste brasileiro.

Além disso, esperava-se que mesmo com a concentração dos investimentos e empresas turísticas na capital do estado a regionalização via polo de crescimento iria possibilitar um efeito de arrasto para os outros municípios litorâneos do polo, tanto ao norte quanto ao sul de Natal, garantindo para os outros lugares turístico um desenvolvimento econômico em função desta atividade, na qual viriam a oferecer um produto turístico para competitivo no cenário turístico de Sol e Praia.

Entretanto, com exceção de Natal e Tibau do Sul, o único município do polo que possui no turismo sua principal fonte de renda, o turismo enquanto atividade econômica, após duas décadas e meia dos primeiros investimentos do PRODETUR/NE no estado, não conseguiu promover um desenvolvimento econômico significativo para os municípios litorâneos.

A insuficiência do turismo enquanto possibilidade real para o desenvolvimento dos demais municípios litorâneos do PCD contrapõem sua ideia original presente na sua oficialização via Decreto Estadual $\mathrm{N}^{\circ} 18.186 / 2005$, que preconizava que essa região é composta por um espaço homogêneo competitivo, ao invés de espaço homogêneo o PCD é composto por regiões desiguais, onde o Litoral Norte possui os piores indicadores econômicos, sociais e turístico, sendo esses municípios os que menos se beneficiam do turismo enquanto atividade econômica. Além do que, a maioria dos produtos turísticos dos 
Abordagem geográfica do Polo Costa das Dunas/RN

ALMADA, J. A. B. de

lugares turísticos que compõem o Litoral Norte não conseguiram ser competitivos, pois há uma baixa oferta turística derivada, consolidando-se a região menos desenvolvida pelo turismo.

\section{Referências}

ALMADA, José Alexandre Berto De. Espaço Geográfico e existencialismo: leitura de Sartre em Milton Santos. Revista de Geografia-PPGEO-UFJF, v.3, n. 2, 2013.

ALVES, Gilson Fernando. Avaliação da cidadania participativa no PRODETUR/NE-II: o caso do Conselho de Turismo do Polo Costa das Dunas. Dissertação (Mestrado Profissional em Avaliação de Políticas Públicas). UECE. Fortaleza, 2009.

BANCO DO NORDESTE DO BRASIL S.A. Relatório de Gestão. 2002.

BANCO DO NORDESTE DO BRASIL S.A. Relatório Final de Projeto -Programa de Desenvolvimento do Turismo no Nordeste - Primeira Fase. 2005.

BENI, Mário Carlos. Análise Estrutural do Turismo. 6 ed. São Paulo: Senac, 2001.

BEZERRA, Josenildo Soares; ARAÚJO, Josélia Carvalho de. Zona Norte: entre o estigma de exclusão/discriminação e a tentativa de reafirmação. In: SÁ, Alcindo José. Por uma Geografia sem cárceres públicos ou privados. UFPE: Recife, 2007, p. 166-176.

BRASIL. Plano de desenvolvimento integrado do turismo sustentável - PDITS POLO COSTA BRANCA - Versão Final. Brasília, 2011.

BRASIL. Portal Brasileiro de Dados Abertos. Categorização dos Municípios Turísticos. 2018, disponível em <<http://dados.gov.br/dataset/categorizacao〉>. Acesso em 19 de jul. de 2019.

COUZON, Isabelle. "Les espaces économiques" de François Perroux (1950). Organisation de l'espace et aménagement du territoire dans l'économie et la géographie françaises au milieu du XXème siècle. Revue d'Histoire des Sciences Humaines. N.9, 2003, p.81-102.

EQUIPE PCR. Relatório de término de projeto: Projeto: Programa de Desenvolvimento do Turismo no Nordeste (Prodetur/NE II). 2012.

HAESBAERT, Rogério. Regional-global: Dilemas da região e da regionalização na geografia contemporânea. 2 ed. Rio de Janeiro: Bertrand Brasil, 2014.

HAESBAERT, Rogério. Região. Geographia. V.21, n.45, 2019, p.117-120.

IBGE. Cidades. Disponível em $<<$ https://cidades.ibge.gov.br/>>. Acesso em 10 de out. de 2019a.

IBGE. Produto Interno Bruto do Municípios. Disponível em $<<$

https://www.ibge.gov.br/estatisticas/economicas/contas-nacionais/9088-produto-interno-bruto-dosmunicipios.html?=\&t=resultados $\gg$. Acesso em 06 de jun. de $2019 \mathrm{~b}$.

IBGE. Brasil em síntese. Disponível em $<<$ https://brasilemsintese.ibge.gov.br/contas-nacionais/pibper-capita.html > . Acesso em 02 de fev. de 2020 
LIMA, Ana Carolina da; SIMÕES, Rodrigo Ferreira. Teorias do desenvolvimento regional e suas implicações de política econômica no pós-guerra: o caso do Brasil. Belo Horizonte:

UFMG/Cedeplar, 2009.

MINISTÉRIO DO TRABALHO. Bases Estatísticas RAIS e CAGED. Disponível em $<<$ http://bi.mte.gov.br/bgcaged/inicial.php > . Acesso em 24 de jan. de 2020.

MEDEIROS, Thiago Belo de. O turismo de sol e praia e o circuito inferior da economia urbana: um estudo a partir da praia de Ponta Negra - Natal/RN. Dissertação em Geografia. UFRN, 2014.

NATAL ONLINE. Passeios e atrações. Disponível em $<<$ https://www.natalonline.com/passeios-eatracoes $>$. Acesso em 06 de nov. de 2019.

NUNES, Elias. Geografia Física do Rio Grande do Norte. Natal: Imagem Gráfica, 2006.

OLIVEIRA, Juliano Varela de. Cidades e turismo sustentável: a cooperação interinstitucional no Conselho de Desenvolvimento do Turismo do Pólo Costa das Dunas/RN. Dissertação (Mestrado em Desenvolvimento Regional; Cultura e Representações). UFRN. Natal, 2006.

PEDROZA, Breno Viotto. A recepção da teoria dos polos de crescimento no Brasil. Terra Brasilis (Nova Série). N.9, 2017, p.1-14.

RIO GRANDE DO NORTE. Decreto No 18.186 , de 14 de abril de 2005. Institui o Polo Costa das Dunas e dá outras Providências. 2005.

RIO GRANDE DO NORTE. Decreto No 26.661, de 20 de fevereiro de 2017. Dispõe sobre os Polos Turísticos do estado do Rio Grande do Norte e dá outras providências. 2017.

SANTOS, Milton. Sous-déveleppement et poles croissance économique et sociale. Revue TiersMonde. Press Universitaire de France, 1974, p. 271-286.

SANTOS, Milton. Espaço dividido. São Paulo: Edusp, 2008.

SANTOS, Milton. A Natureza do Espaço: Técnica e Tempo; Razão e Emoção. São Paulo: Edusp, 2012.

SETUR. Indicadores básicos do turismo 2006/2012. Natal, 2013.

THÉRY, Herve. Lieux et flux du tourisme intérieur brésilien. Via Tourism Review. 2015. 